\title{
Methane emission from soil under long-term no-till cropping systems
}

\author{
Cimélio Bayer $^{\mathrm{a}, *}$, Juliana Gomes ${ }^{\mathrm{a}}$, Frederico Costa Beber Vieira ${ }^{\mathrm{b}}$, Josiléia Accordi Zanatta ${ }^{\mathrm{c}}$, \\ Marisa de Cássia Piccolo ${ }^{\mathrm{d}}$, Jeferson Dieckow ${ }^{\mathrm{e}}$ \\ ${ }^{a}$ Departamento de Solos, Universidade Federal do Rio Grande do Sul, 91540-000 Porto Alegre, RS, Brazil \\ ${ }^{\mathrm{b}}$ Universidade Federal do Pampa, Av. Antônio Trilha, 1847, 97300-000 São Gabriel, RS, Brazil \\ ${ }^{\mathrm{C}}$ Empresa Brasileira de Pesquisa Agropecuária, P.O. Box 319, 83411-000, Colombo, PR, Brazil \\ ${ }^{\mathrm{d}}$ Centro de Energia Nuclear na Agricultura, Universidade de São Paulo, P.O. Box 096, 13416-000 Piracicaba, SP, Brazil \\ e Departamento de Solos e Engenharia Agrícola, Universidade Federal do Paraná, 80.035-050 Curitiba, PR, Brazil
}

\section{A R T I C L E I N F O}

\section{Article history:}

Received 9 November 2011

Received in revised form 14 March 2012

Accepted 15 March 2012

\section{Keywords:}

Global warming

Agricultural soils

Methane uptake

Subtropical climate

\begin{abstract}
A B S T R A C T
Methane $\left(\mathrm{CH}_{4}\right)$ emission from agricultural soils increases dramatically as a result of deleterious effect of soil disturbance and nitrogen fertilization on methanotrophic organisms; however, few studies have attempted to evaluate the potential of long-term conservation management systems to mitigate $\mathrm{CH}_{4}$ emissions in tropical and subtropical soils. This study aimed to evaluate the long-term effect ( $>19$ years) of no-till grass- and legume-based cropping systems on annual soil $\mathrm{CH}_{4}$ fluxes in a formerly degraded Acrisol in Southern Brazil. Air sampling was carried out using static chambers and $\mathrm{CH}_{4}$ analysis by gas chromatography. Analysis of historical data set of the experiment evidenced a remarkable effect of high $\mathrm{C}$ - and $\mathrm{N}$-input cropping systems on the improvement of biological, chemical, and physical characteristics of this no-tilled soil. Soil $\mathrm{CH}_{4}$ fluxes, which represent a net balance between consumption (-) and production (+) of $\mathrm{CH}_{4}$ in soil, varied from $-40 \pm 2$ to $+62 \pm 78 \mu \mathrm{g} \mathrm{C} \mathrm{m}^{-2} \mathrm{~h}^{-1}$. Mean weighted contents of ammonium $\left(\mathrm{NH}_{4}{ }^{+}-\mathrm{N}\right)$ and dissolved organic carbon (DOC) in soil had a positive relationship with accumulated soil $\mathrm{CH}_{4}$ fluxes in the post-management period $\left(r^{2}=0.95, p=0.05\right)$, suggesting an additive effect of these nutrients in suppressing $\mathrm{CH}_{4}$ oxidation and stimulating methanogenesis, respectively, in legumebased cropping systems with high biomass input. Annual $\mathrm{CH}_{4}$ fluxes ranged from $-50 \pm 610$ to $+994 \pm 105 \mathrm{~g}$ $\mathrm{C} \mathrm{ha}^{-1}$, which were inversely related to annual biomass-C input $\left(r^{2}=0.99, p=0.003\right)$, with the exception of the cropping system containing pigeon pea, a summer legume that had the highest biologically fixed $\mathrm{N}$ input $\left(>300 \mathrm{~kg} \mathrm{ha}^{-1} \mathrm{yr}^{-1}\right)$. Our results evidenced a small effect of conservation management systems on decreasing $\mathrm{CH}_{4}$ emissions from soil, despite their significant effect restoring soil quality. We hypothesized that soil $\mathrm{CH}_{4}$ uptake strength has been off-set by an injurious effect of biologically fixed $\mathrm{N}$ in legume-based cropping systems on soil methanotrophic microbiota, and by the methanogenesis increase as a result of the $\mathrm{O}_{2}$ depletion in niches of high biological activity in the surface layer of the no-tillage soil.
\end{abstract}

(c) 2012 Elsevier B.V. All rights reserved.

\section{Introduction}

Methane $\left(\mathrm{CH}_{4}\right)$ is one of the main anthropogenic greenhouse gases, which contribution to global warming is estimated in $20 \%$ (IPCC, 2007). Soil $\mathrm{CH}_{4}$ fluxes are a net result of the $\mathrm{CH}_{4}$ production (+) by methanogenesis and $\mathrm{CH}_{4}$ oxidation (-) by methanotrophy processes (Ball et al., 1999; Baggs et al., 2006). Usually, undisturbed soils act as a net $\mathrm{CH}_{4}$ sink, but a dramatic decrease on the $\mathrm{CH}_{4}$ oxidation rates is experienced when soils are converted to agriculture, which effect has been mainly related to the soil disturbance and to the ammonium-based $\mathrm{N}$ fertilization (Baggs and Blum, 2004; Hutsch, 1998a,b; Mojeremane et al., 2011; Powlson et al., 1997; Suwanwaree and Robertson, 2005). Tillage creates an

\footnotetext{
* Corresponding author. Tel.: +55 513308 6017; fax: +55 5133086040

E-mail address: cimelio.bayer@ufrgs.br (C. Bayer).
}

inhospitable environment to methanotrophic organisms (Hutsch, 1998a; Willison et al., 1995), while increased soil $\mathrm{NH}_{4}{ }^{+}$contents compete with $\mathrm{CH}_{4}$ for the methane mono-oxygenase enzyme (Acton and Baggs, 2011; Bender and Conrad, 1992; Hutsch, 2001; Knief et al., 2005). As a result of the decrease on soil $\mathrm{CH}_{4}$ sink to the increase of anthropogenic $\mathrm{CH}_{4}$ sources, a net significant amount of $32 \mathrm{Tg}$ of $\mathrm{CH}_{4}$ has been annually increased in the atmosphere (UNEP, 1993).

Implementation of conservation tillage systems has been suggested as a key strategy to decrease $\mathrm{CH}_{4}$ emissions to atmosphere by restoring $\mathrm{CH}_{4}$ sink strength in agricultural soils (Hutsch, 1998a; Kessavalou et al., 1998; Ussiri et al., 2009), which effect is attributed to the more favorable biological, chemical, and physical soil environments to microorganisms in general, as well as to methanotrophic bacteria (Hutsch, 2001, 1998a). However, most studies have evidenced a little effect of soil management on soil $\mathrm{CH}_{4}$ emissions evidencing that the recovery of methanotrophic activity in agricultural soils is a very slow process, and several 
decades may be required for providing a significant effect of the conservation tillage systems on soil $\mathrm{CH}_{4}$ sink strength (Jacinthe and Lal, 2005, 2006; Ojima et al., 1993; Priemé et al., 1997; Regina and Alakukku, 2010; Suwanwaree and Robertson, 2005).

Grass and legume cover crops-based cropping systems have profound impact on soil quality, but their potential effect on $\mathrm{CH}_{4}$ emissions in no-tillage soils is unknown. High biomass input by legume cover crops-based cropping systems increases the soil organic matter content and lability, aggregation, and microbial biomass and activity (Amado et al., 2006; Bayer et al., 2000; Kong et al., 2005; Vieira et al., 2007, 2008), which changes may be potentially favorable to methanotrophic bacteria as evidenced for organically fertilized soils (Seghers et al., 2003). However, biological oxidation of large quantity of labile $C$, as from narrow $\mathrm{C}: \mathrm{N}$ crop residues, may result in an intense $\mathrm{O}_{2}$ consumption, mostly in niches of high biological activity in soil, creating favorable conditions to methanogenesis (Baggs et al., 2006; Topp and Pattey, 1997). Thus, the net effect of this practice on $\mathrm{CH}_{4}$ fluxes will be dependent on the balance between these opposite effects.

Smaller requirements of mineral $\mathrm{N}$ fertilizer by the cash crop in legume cover crops-based cropping systems (Fontoura and Bayer, 2009) may also have a benefic effect on soil $\mathrm{CH}_{4}$ oxidation; nevertheless, no information is available regarding the injurious effect of long-term biologically fixed $\mathrm{N}$ input on methanotrophic population. Only the immediate or short-term deleterious effect of increased ammonium $\left(\mathrm{NH}_{4}{ }^{+}\right)$soil content on $\mathrm{CH}_{4}$ oxidation capacity of legume crop residues-amended soils has been characterized (Boeckx and Van Cleemput, 1996; Tlustos et al., 1998), which is related to competitive enzymatic process between methanotrophy and nitrification in soils (Baggs and Blum, 2004; Bender and Conrad, 1992; Hutsch, 2001). The long-term effect of $\mathrm{N}$ input for several decades on soil $\mathrm{CH}_{4}$ oxidation is probably a slow and not fully reversible process in agricultural soils (Chan and Parkin, 2001; Hutsch, 2001; Suwanwaree and Robertson, 2005), and might be related to changes in the microbial community structure (Suwanwaree and Robertson, 2005).

Based on scarce information available in literature concerning the effect of cropping systems on $\mathrm{CH}_{4}$ emissions in tropical and subtropical soils, this study was developed in two long-term experiments ( $>19$ years) aiming to evaluate the potential of high biomass- $\mathrm{C}$ and biologically fixed $\mathrm{N}$ inputs by no-till cropping systems for decreasing $\mathrm{CH}_{4}$ emissions from a previously degraded South Brazilian Acrisol. Historical data concerning the influence of cropping systems on soil quality were also analyzed.

\section{Material and methods}

\subsection{Long-term experiments and historical data set of soil quality}

The study was carried out in two adjacent long-term experiments initiated in 1983 (Exp. I) and 1985 (Exp. II), at a formerly degraded Aluminic Acrisol (220 clay kg ${ }^{-1}$ ) in subtropical climate (annual mean temperature and rainfall of $19.4^{\circ} \mathrm{C}$ and $1440 \mathrm{~mm}$, respectively) from Southern Brazil $\left(30^{\circ} 06^{\prime} \mathrm{S} ; 51^{\circ} 41^{\prime} \mathrm{W}\right.$, about $45 \mathrm{~m}$ altitude). Previous soil degradation was caused by the intense plowing and erosion due to the conventional tillage adopted over almost two decades.

Selected cropping systems involving grass and legume covercrops [Exp. I: black oat (Avena strigosa Schreb) + vetch (Vigna sativa L.)/maize (Zea mays L.) + cowpea (Vigna unguiculata Walp)-O + V/ $\mathrm{M}+\mathrm{C}$, pigeon pea (Cajanus cajan $\mathrm{L}$.) + maize-P $+\mathrm{M}$, and lablab (Dolichos lablab) + maize-L + M; Exp. II: black oat/maize-O/M and vetch/maize-(V/M)] were evaluated. All cropping systems were conducted under no-tillage system, where crop residues of winter and summer cover-crops and of maize were maintained on soil surface, and no mineral $\mathrm{N}$ fertilizer was applied in any treatment for 20 (Exp. I) and 19 years (Exp. II). Phosphorus and potassium were applied annually for maize at rates of $60 \mathrm{~kg} \mathrm{ha}^{-1}$ of $\mathrm{P}_{2} \mathrm{O}_{5}$ and $\mathrm{K}_{2} \mathrm{O}$.

Winter cover-crops were sown in April (autumn in the South Hemisphere) and maize in September or October (spring in the South Hemisphere). A seed rate of $60-80 \mathrm{~kg} \mathrm{ha}^{-1}$ was used for winter cover-crops, while maize was sown at 50,00070,000 seeds ha $^{-1}$. In the first 7 (Exp. I) and 5 years (Exp. II), all crops were sown manually, and a mechanical sowing of winter cover-crops and maize was performed in the subsequent period. Summer cover-crops were intercropped with maize; they were manually sown in spring-summer at the maize inter-rows, with an average of three seeds per hole and distance of $40-50 \mathrm{~cm}$ between holes. No pesticides were applied in any cropping system, excepting the glyphosate-based herbicide applied every spring season for the winter cover-crops management, followed by rollercutter in about 1 week later. Additional information concerning the experiments is available in Zanatta et al. (2007) and Vieira et al. (2008).

Historical data regarding annual biomass- $\mathrm{C}$ and $-\mathrm{N}$ inputs, and the influence of long-term cropping systems on biological, chemical and physical soil quality indicators are summarized in Table 1.

\subsection{Air sampling and $\mathrm{CH}_{4}$ flux calculation}

In Oct 30th 2003, after the management of cover-crops, a $2 \mathrm{~m} \times 2 \mathrm{~m}$ area was defined in one plot of each treatment, and two aluminum-made bases were fixed in the soil. Air sampling was performed for a period of 344 days (from Nov 5th 2003 to Oct 13th 2004), in weekly intervals in the first 45 days after the management of cover crops, and intervals varying from 15 to 60 days in the later period (Fig. 1).

Air samples were manually taken from closed flux chambers ( $0.25 \mathrm{~m}$ diameter $\times 0.20 \mathrm{~m}$ height) composed of a PVC-cylinder with the top border hermetically closed. At the time of the gas measurement this chamber was fitted on to an aluminum base $\left(0.0346 \mathrm{~m}^{2}\right)$ equipped at the top with a circular channel (diameter of 0.21 and $0.28 \mathrm{~m}$ of inner and outer ring, respectively, and height of $0.05 \mathrm{~m}$ ) inserted $5 \mathrm{~cm}$ into the soil, which was only removed from the field at the sowing and harvesting events. To ensure a good seal between the base and the PVC chamber, water was added to the channel in the lower base. The chambers had a thermometer with outside display for monitoring the temperature of the inward air, and an internal fan for homogenizing the chamber atmosphere before the sampling. In the top, the chambers were equipped with a rubber septum for sampling the air. This apparatus is similar to that used by Gomes et al. (2009) and Zanatta et al. (2010).

Air samples were taken simultaneously in all treatments, beginning at 9 a.m. and taking samples at $0,15,30$ and 45 min after closing the chamber. The syringes (polypropylene, $20 \mathrm{~mL}$ ) were closed and immediately disposed in a cooler box, where they were kept at low temperature, and dispatched by express mail to the Environmental Biogeochemical Lab (Nuclear Energy Centre, University of Sao Paulo) for analysis of $\mathrm{CH}_{4}$ concentration by gas chromatography (GC-Shimadzu 14A), within 24 h of sampling. The chromatograph was equipped with a Porapak-Q column set at $30{ }^{\circ} \mathrm{C}$ temperature, $\mathrm{N}_{2}$ as carrier gas in flow of $30 \mathrm{~mL} \mathrm{~min}^{-1}$, injector temperature of $50{ }^{\circ} \mathrm{C}$, and FID detector at temperature of $320^{\circ} \mathrm{C}$.

The $\mathrm{CH}_{4}$ fluxes were calculated using the following equation by Hutchinson and Livingston (1993): $f=(\Delta C / \Delta t) \times(V / A) \times\left(m / V_{m}\right)$; where: $f$ is the flux of soil $\mathrm{CH}_{4}$ gas $\left(\mu \mathrm{g} \mathrm{C} \mathrm{m}^{-2} \mathrm{~h}^{-1}\right), \Delta C / \Delta t$ is the rate of change for the gas concentration inside the measuring chamber ( $\left.\mu \mathrm{g} \mathrm{Ch}^{-1}\right), V$ is the headspace volume of the chamber $\left(0.00982 \mathrm{~m}^{3}\right), A$ is the circular area of the bases $\left(0.0346 \mathrm{~m}^{2}\right)$, 
Table 1

Summary of historical soil quality data set from the two long-term experiments in Southern Brazil.

\begin{tabular}{|c|c|c|c|c|c|c|c|c|}
\hline \multirow[t]{2}{*}{ Soil quality indicator ${ }^{\mathrm{a}}$} & \multirow[t]{2}{*}{ Time $^{\mathrm{b}}$ (years) } & \multirow[t]{2}{*}{ Depth $(\mathrm{cm})$} & \multicolumn{5}{|c|}{ Cropping systems $^{\mathrm{c}}$} & \multirow[t]{2}{*}{ Reference $^{\mathrm{d}}$} \\
\hline & & & $\mathrm{O} / \mathrm{M}$ & $\mathrm{V} / \mathrm{M}$ & $\mathrm{O}+\mathrm{V} / \mathrm{M}+\mathrm{C}$ & $\mathrm{L}+\mathrm{M}$ & $\mathrm{P}+\mathrm{M}$ & \\
\hline Mean annual $\mathrm{C}$ input $\left(\mathrm{Mg} \mathrm{ha}^{-1}\right)$ & 19 & - & 4.00 & 5.75 & 6.60 & 6.27 & 7.84 & 1,2 \\
\hline Annual $\mathrm{N}$ input by cover crops $\left(\mathrm{kg} \mathrm{ha}^{-1}\right)$ & 19 & - & 40 & 114 & 140 & 128 & 327 & 4 \\
\hline \multicolumn{9}{|l|}{ Biological } \\
\hline Microbial biomass ( $\mathrm{mg} \mathrm{C} \mathrm{kg}{ }^{-1}$ soil) & 17 & $0-10.0$ & 410 & - & 469 & - & 428 & 3 \\
\hline Microbial activity ( $\mathrm{mg} \mathrm{C} \mathrm{kg}^{-1}$ soil) & 17 & $0-10.0$ & 100 & - & 135 & - & 154 & 3 \\
\hline$\beta$-Glucosidade ( $\mu$ g p-nitrophenol g ${ }^{-1}$ soil) & 17 & $0-10.0$ & 97 & - & 135 & - & 146 & 3 \\
\hline Amidase $\left(\mu \mathrm{g} \mathrm{NH}_{4}^{+}-\mathrm{Ng}^{-1}\right.$ soil $)$ & 17 & $0-10.0$ & 199 & - & 228 & - & 267 & 3 \\
\hline \multicolumn{9}{|l|}{ Chemical } \\
\hline $\mathrm{SOC}$ ( $\mathrm{g} \mathrm{C} \mathrm{kg}^{-1}$ soil) & 19 & $0-12.5$ & 10.88 & 12.79 & 12.68 & 17.15 & 14.69 & 1,2 \\
\hline Total soil $\mathrm{N}$ ( $\mathrm{g} \mathrm{N} \mathrm{kg}^{-1}$ soil $)$ & 19 & $0-12.5$ & 1.07 & 1.16 & 1.94 & 1.37 & 1.40 & 4,5 \\
\hline Labile-C ( $\mathrm{g} \mathrm{C} \mathrm{kg}^{-1}$ soil) & 19 & $0-12.5$ & 0.48 & - & 0.82 & - & 1.45 & 1 \\
\hline CEC at $\mathrm{pH} 7.0\left(\mathrm{cmol}_{\mathrm{c}} \mathrm{kg}^{-1}\right.$ soil $)$ & 19 & $0-12.5$ & 7.20 & 11.30 & 9.98 & 11.62 & 10.53 & 4,5 \\
\hline \multicolumn{9}{|l|}{ Physical } \\
\hline MWD wet (mm) & 21 & $0-10.0$ & 2.80 & - & 2.90 & 3.70 & - & 6 \\
\hline Total soil porosity $\left(\mathrm{m}^{3} \mathrm{~m}^{-3}\right.$ soil $)$ & 18 & $0-10.0$ & 0.40 & - & 0.38 & - & 0.38 & 2,6 \\
\hline
\end{tabular}

a SOC: soil organic carbon; CEC: cation exchange capacity; MWD: mean weight diameter.

b Time of the experiment when soil variable was evaluated.

c Exp. I: $\mathrm{O}+\mathrm{V} / \mathrm{M}+\mathrm{C}=$ black oat (Avena strigosa Schreb) + vetch (Vigna sativa $\mathrm{L}$.)/maize (Zea mays L.) + cowpea (Vigna unguiculata Walp); $\mathrm{P}+\mathrm{M}=$ pigeon pea (Cajanus cajan L.) + maize; $\mathrm{L}+\mathrm{M}=$ lablab (Dolichos lablab) + maize; Exp. II: O/M = black oat $/ \mathrm{maize} ; \mathrm{V} / \mathrm{M}=\mathrm{vetch} / \mathrm{maize}$.

d (1) Vieira et al. (2007); (2) Zanatta et al. (2007); (3) Schmitz (2003); (4) Vieira (2007); (5) Zanatta (2006); (6) Vieira et al. (2008).

$m$ is the molecular weight of the gas $\left(16 \mathrm{~g} \mathrm{~mol}^{-1}\right)$, and $V_{m}$ is the molar volume of gas $\left(\mathrm{m}^{3} \mathrm{~mol}^{-1}\right)$ corrected for the air temperature $(\mathrm{K})$ in the headspace chamber, measured at the sampling time.

Mean $\mathrm{CH}_{4}$ fluxes ( $\mu \mathrm{g} \mathrm{C} \mathrm{m}^{-2} \mathrm{~h}^{-1}$ ) and respective standard deviations were calculated from the fluxes measured in the two chambers per treatment. Daily $\mathrm{CH}_{4}-\mathrm{C}$ fluxes were estimated by linear interpolation assuming that the 9:00-10 a.m. sampling period provided a valid estimation of average daily $\mathrm{fCH}_{4}$. This assumption is supported by the results reported by Jantalia et al. (2008), who observed that, for the same region, the middle of the morning was the most feasible time for air sampling aiming to estimate mean daily $\mathrm{N}_{2} \mathrm{O}$ fluxes. Cumulative fluxes for 1 year and for the post-management period (90 days after winter cover-crop management) were calculated by integration of the daily $\mathrm{CH}_{4}$ emissions.

\subsection{Soil variables}

The first 11 sampling events for $\mathrm{CH}_{4}$ analyzes were joined by evaluations of soil gravimetric moisture, dissolved organic carbon (DOC), and ammonium $\left(\mathrm{NH}_{4}{ }^{+}\right)$contents in composite soil samples (4 sub-samples) at $0-0.3 \mathrm{~m}$ depth, and soil temperature at $0.05 \mathrm{~m}$ depth, within the $2 \mathrm{~m} \times 2 \mathrm{~m}$ area. Geo-thermometers were used to evaluate soil temperature. The gravimetric moisture was obtained by drying up the soil at $105{ }^{\circ} \mathrm{C}$ for $48 \mathrm{~h}$. Samples for DOC analysis were air dried, ground, and sieved through a $2 \mathrm{~mm}$ sieve. The DOC was extracted by horizontally shaking a solution with $5 \mathrm{~g}$ soil and $50 \mathrm{~mL}$ distilled water $(1: 10)$ for $10 \mathrm{~h}$. The suspension was centrifuged and the supernatant filtrated through regenerated cellulose membrane filters of $0.45 \mu \mathrm{m}$ pore diameter (Chantigny, 2003). The DOC contents were determined by dry combustion using a TOC VCSH Analyzer Shimadzu ${ }^{\mathbb{R}}$. Ammonium was extracted with $1 \mathrm{M} \mathrm{KCl}$ and determined by Kjeldhal distillation method (Bremner, 1960). Based on results of gravimetric water content and soil bulk density for each crop system, reported by Vieira et al. (2008) for the experiment I and by Zanatta et al. (2007) for the experiment II, the percentage of water-filled pore space (WFPS) was calculated for each sampling date, assuming a mineral particle density of $2.65 \mathrm{~g} \mathrm{~cm}^{-3}$. Local data of air temperature and rainfall for the evaluated period (Fig. 2) were obtained from an Automatic Meteorological Station at the Department of Forage and Meteorology (UFRGS), which is located about $1 \mathrm{~km}$ from the experimental area.

\subsection{Statistical analysis}

Considering that measurements of $\mathrm{CH}_{4}$ were accomplished with two chambers in the same plot and, thus, the evaluations

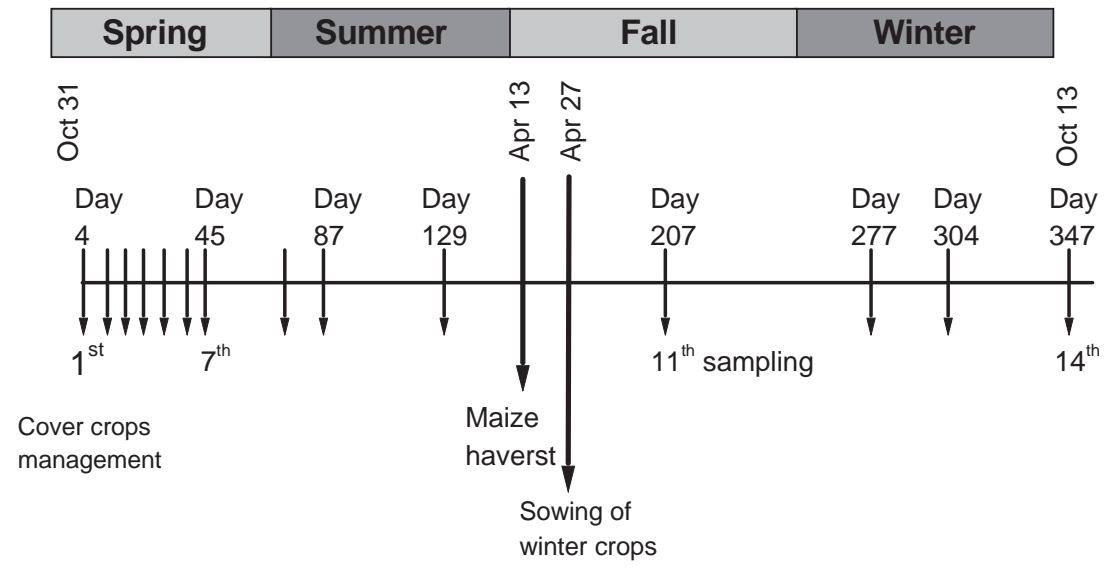

Fig. 1. Schedule of air sampling and agricultural practices. 


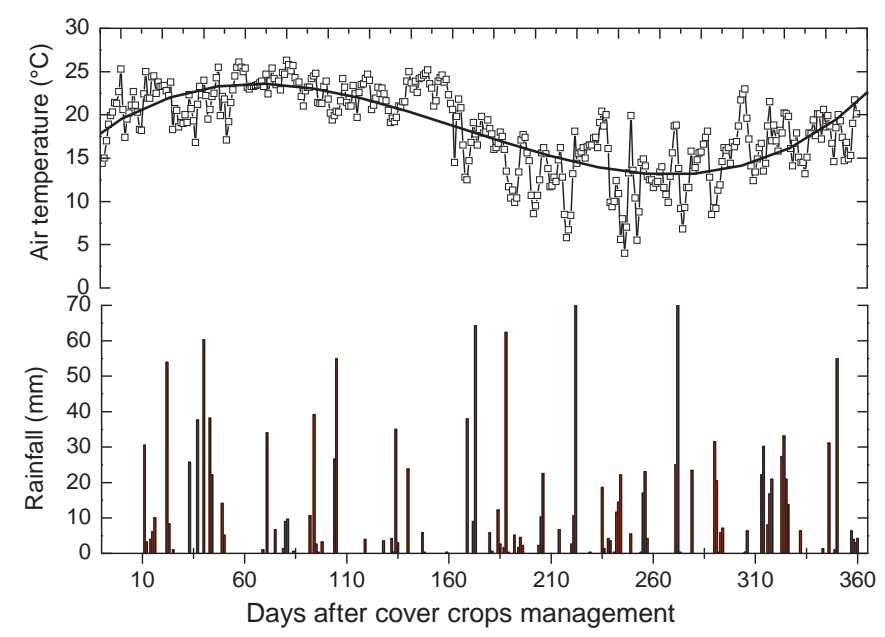

Fig. 2. Air temperature and rainfall along of the air sampling period.

were not taken in the field replicates, a non-descriptive statistical analyses was performed and the mean standard deviation values were used to discriminate the effect of cropping systems on soil $\mathrm{CH}_{4}$ emissions. Relationship between soil variables and $\mathrm{CH}_{4}$ emissions was evaluated by the significance of determination coefficient $\left(r^{2}\right)$ of simple and multiple linear regressions.

\section{Results}

\subsection{Brief comments on long-term no-till cropping systems effect on soil quality}

Historical soil quality data are summarized in Table 1. A remarkable effect of the high aboveground biomass- $C$ input by legume cover crops-based cropping systems (5.757.84 $\mathrm{Mg} \mathrm{ha}^{-1} \mathrm{yr}^{-1} ; \mathrm{V} / \mathrm{M}, \mathrm{O}+\mathrm{V} / \mathrm{M}+\mathrm{C}, \mathrm{P}+\mathrm{M}$, and $\left.\mathrm{L}+\mathrm{M}\right)$ on the enhancement of the biological, chemical, and physical soil quality indicators was observed in this no-tilled soil, in comparison to lower biomass-C input grass-based cropping system (4.00 $\left.\mathrm{Mg} \mathrm{ha}^{-1} \mathrm{yr}^{-1} ; \mathrm{O} / \mathrm{M}\right)$. Among the soil variables, we underline the potential of the summer and winter cover-crops to improve the soil organic matter content and lability, microbial biomass- $\mathrm{C}$ and its activity $\left(\mathrm{CO}_{2}-\mathrm{C}\right)$, enzymatic activity, and soil aggregation (Table 1 ).

\subsection{Soil methane fluxes and soil variables}

Soil $\mathrm{CH}_{4}$ fluxes in cropping systems varied from $-40 \pm 2$ to $+62 \pm 33 \mu \mathrm{g} \mathrm{C} \mathrm{m}{ }^{-2} \mathrm{~h}^{-1}$ (Fig. 3). The greatest oscillation in the soil $\mathrm{CH}_{4}$ fluxes occurred in the first 3 months after the cover crops management in this no-tillage soil (post-management period, Fig. 3), concomitantly to the period in which the highest oscillation in soil variables were observed, mainly $\mathrm{NH}_{4}{ }^{+}\left(0.04-9.10 \mathrm{mg} \mathrm{N} \mathrm{kg}^{-1}\right.$ soil) and DOC (0.13-0.36 $\mathrm{mg} \mathrm{C} \mathrm{kg}^{-1}$ soil) contents (Fig. 4).

In the post-management period, predominance of net $\mathrm{CH}_{4}$ emission to atmosphere was observed in soil under tropical legume cover crops-based cropping systems $(P+M$ and $L+M)$, reaching peaks up to $+62 \pm 33 \mu \mathrm{g} \mathrm{C} \mathrm{m}{ }^{-2} \mathrm{~h}^{-1}$. In contrast, soils under winter legume $(\mathrm{V} / \mathrm{M})$, mixed system $(\mathrm{O}+\mathrm{V} / \mathrm{M}+\mathrm{C})$, and grass cover cropsbased cropping system $(\mathrm{O} / \mathrm{M})$ had predominantly net $\mathrm{CH}_{4}$ uptake (Fig. 3), reaching net $\mathrm{CH}_{4}$ oxidation rates up to $-27 \pm 10 \mu \mathrm{g} \mathrm{C} \mathrm{m}^{-2} \mathrm{~h}^{-1}$ (Fig. 3). This distinct behavior of cropping systems was reflected in the cumulative soil $\mathrm{CH}_{4}$ fluxes in the post-management period. Summer cover crops-based cropping systems had a net $\mathrm{CH}_{4}$ emission to atmosphere $\left(+90 \pm 60 \mathrm{~g} \mathrm{Cha}^{-1}\right.$ in $\mathrm{L}+\mathrm{M}$ and $+334 \pm 18 \mathrm{~g} \mathrm{Cha}^{-1}$ in $\mathrm{P}+\mathrm{M}$ ), while the soil under the other cropping systems had a net $\mathrm{CH}_{4}$ oxidation, ranging from $-191 \pm 201$ to $-132 \pm 102 \mathrm{~g} \mathrm{C} \mathrm{ha}^{-1}$.

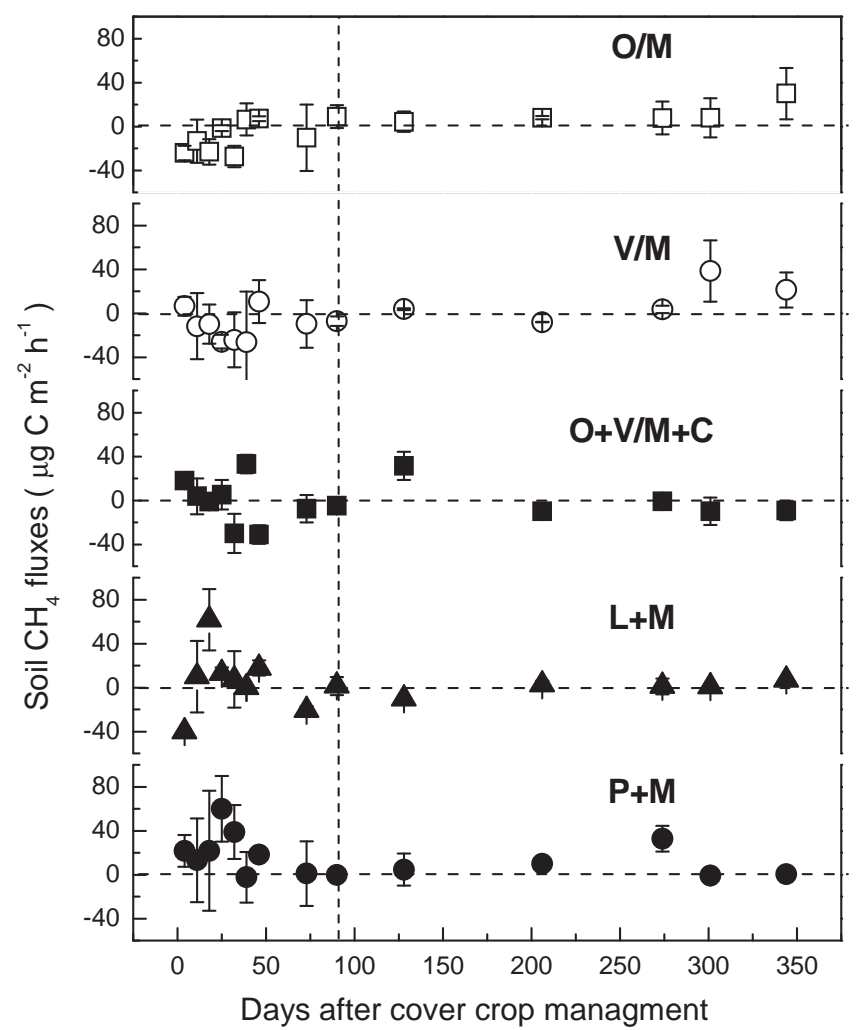

Fig. 3. Methane fluxes in subtropical Acrisol under five long-term no-till cropping systems. $\mathrm{O} / \mathrm{M}=$ black oat $/$ maize; $\mathrm{V} / \mathrm{M}=$ vetch/maize; $\mathrm{O}+\mathrm{V} / \mathrm{M}+\mathrm{C}=$ oat + vetch/ maize + cowpea; $\mathrm{L}+\mathrm{M}=$ lablab + maize; and $\mathrm{P}+\mathrm{M}=$ pigeon pea + maize. Vertical bars represent mean standard deviation $(n=2)$, and the dotted vertical line denotes the end limit of the post-management period (90 days after cover crops management).

Individual fluxes of $\mathrm{CH}_{4}$ in the post-management period had no relationship with any soil variable. However, a close relationship was observed between cumulative soil $\mathrm{CH}_{4}$ flux rates and weighted $\mathrm{NH}_{4}{ }^{+}-\mathrm{N}$ and DOC contents in the $0-30 \mathrm{~cm}$ soil layer in the postmanagement period $\left(\mathrm{CH}_{4}-\mathrm{C}\right.$ flux $=-1731+179 \mathrm{NH}_{4}{ }^{+}-\mathrm{N}+4800$ DOC, $\left.r^{2}=0.95, n=5, p=0.05\right)$. After the post-management period, the soil $\mathrm{CH}_{4}$ fluxes were smaller, reaching background values (closed to zero) in the most cropping systems (Fig. 3 ).

Annual soil $\mathrm{CH}_{4}$ fluxes ranged from $-50 \mathrm{~g} \mathrm{C}^{-1}$ in $\mathrm{O}+\mathrm{V} / \mathrm{M}+\mathrm{C}$ to $+994 \mathrm{~g} \mathrm{C}^{-1}$ in $\mathrm{P}+\mathrm{M}$ cropping system (Fig. 5), and apart from the $\mathrm{P}+\mathrm{M}$ system, they have a close and negative relationship with annual aboveground biomass- $\mathrm{C}$ input by the cropping systems (annual soil $\mathrm{CH}_{4}-\mathrm{C}$ flux $=1212-187$ biomass-C input, $r^{2}=0.99$, $p=0.003)$.

\section{Discussion}

The range observed in the soil $\mathrm{CH}_{4}$ fluxes (Fig. 3) was very similar to those reported in a review of 63 studies performed in tropical soils under different soil uses, where most soils $(>80 \%)$ had fluxes varying from -50 to $+50 \mu \mathrm{g} \mathrm{C} \mathrm{m}^{-2} \mathrm{~h}^{-1}$ (Priemé and Christensen, 1999). However, the annual rates $(-50 \pm 310$ to $+994 \pm 105 \mathrm{~g} \mathrm{C} \mathrm{ha}^{-1}$ ) indicated a weaker soil $\mathrm{CH}_{4}$ sink strength in comparison with grassland and mineral arable European soils, which $\mathrm{CH}_{4}$ oxidation rates vary from -86 to $-7800 \mathrm{~g} \mathrm{Cha}^{-1}$ (Boeckx and Van Cleemput, 2001; Smith et al., 2000).

The highest oscillation of soil $\mathrm{CH}_{4}$ fluxes in the post-management period was probably related to the biomass stimulation effect on soil microorganisms resulting from $\mathrm{C}$ and $\mathrm{N}$ input (Figs. 3 and 4), as well as to the higher temperature and moisture conditions in spring and part of the summer seasons (Fig. 2). This 


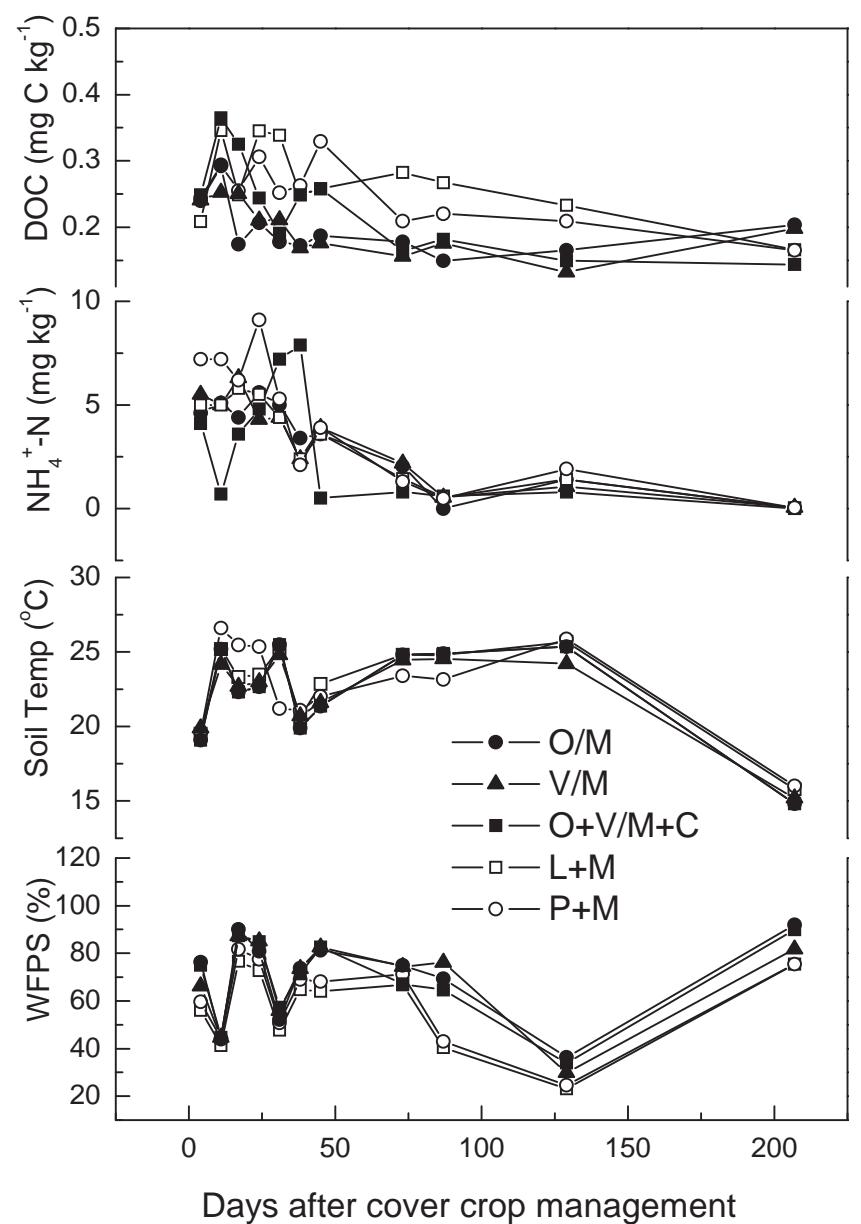

Fig. 4. Dissolved organic carbon (COD), $\mathrm{NH}_{4}{ }^{+}-\mathrm{N}$ concentration, soil temperature (Soil Temp), and water filled pore space (WFPS, \%) in the 0-30 soil layer in an Acrisol under five long-term no-till cropping systems. $\mathrm{O} / \mathrm{M}=$ black oat $/$ maize; $\mathrm{V} / \mathrm{M}=$ vetch/ maize; $\mathrm{O}+\mathrm{V} / \mathrm{M}+\mathrm{C}=$ oat + vetch/maize + cowpea; $\mathrm{L}+\mathrm{M}=$ lablab + maize; and $\mathrm{P}+\mathrm{M}=$ pigeon pea + maize.

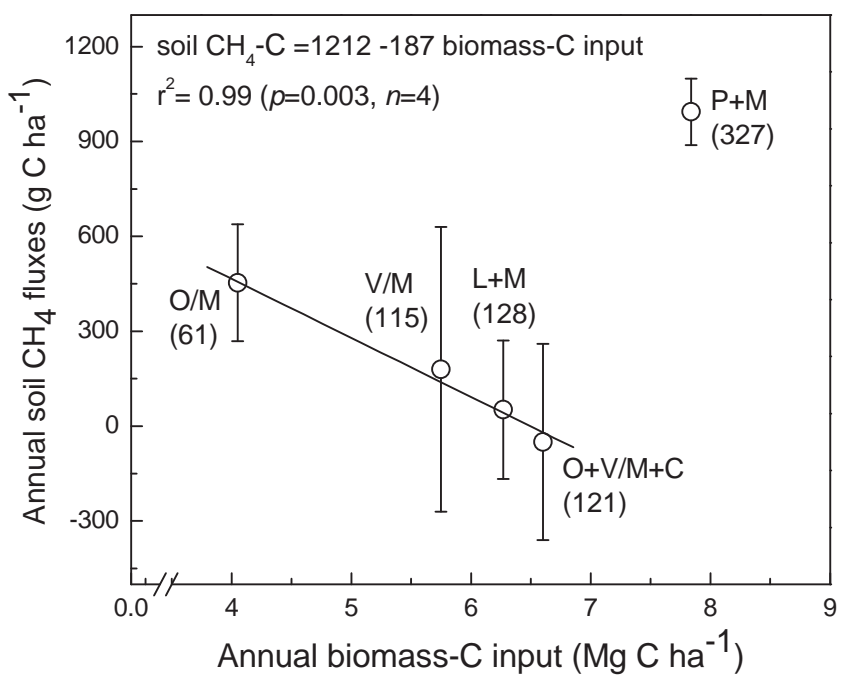

Fig. 5. Relationship between aboveground biomass- $\mathrm{C}$ input and annual $\mathrm{CH}_{4}$ fluxes in an Acrisol under five long-term no-till cropping systems. $\mathrm{O} / \mathrm{M}=$ black oat $/ \mathrm{maize} ; \mathrm{V} /$ $\mathrm{M}=$ vetch/maize $; \mathrm{O}+\mathrm{V} / \mathrm{M}+\mathrm{C}=$ oat + vetch/maize + cowpea $\mathrm{L}+\mathrm{M}=$ lablab + maize; and $\mathrm{P}+\mathrm{M}=$ pigeon pea + maize. Vertical bars represent mean standard deviation $(n=2)$. Values between parentheses denote the annual $\mathrm{N}$ input by cover-crops in each cropping system. Linear equation does not include $\mathrm{P}+\mathrm{M}$ cropping system. interaction between environment and management practices resulted in the most favorable conditions to microbial activity in soil in comparison with the following period.

Soil $\mathrm{CH}_{4}$ fluxes had a close relationship with mean weighted $\mathrm{NH}_{4}{ }^{+}-\mathrm{N}$ and DOC soil contents in the post-management period. These results suggest an additive effect of these nutrients on soil $\mathrm{CH}_{4}$ fluxes, where great $\mathrm{NH}_{4}{ }^{+}-\mathrm{N}$ and DOC contents resulted in a decrease in methanotrophy concomitantly to an increase in methanogenesis, respectively. The injurious short-term effect of $\mathrm{NH}_{4}{ }^{+}$on methanotrophic bacteria in agricultural soils is very well described in the literature concerning the effect of ammoniumbased fertilizer (Acton and Baggs, 2011; Reay and Nedwell, 2004; Sitauta et al., 2000; Suwanwaree and Robertson, 2005); however, few studies have demonstrated this deleterious effect on $\mathrm{CH}_{4}$ oxidation resulting from legume residues (Baggs et al., 2006; Boeckx and Van Cleemput, 1996; Tlustos et al., 1998). The immediate $\mathrm{NH}_{4}{ }^{+}$effect on soil $\mathrm{CH}_{4}$ oxidation is related to the competition between methanotrophs and nitrifiers for the enzyme methane monooxygenase (Bender and Conrad, 1992; Hutsch, 2001). According to Hutsch (1998a), oxidation of $\mathrm{NH}_{4}{ }^{+}$and $\mathrm{CH}_{4}$ exclude each other in soil and $\mathrm{CH}_{4}$ oxidation only occurs after $\mathrm{NH}_{4}{ }^{+}$ nitrification is almost completed. Although mineral $\mathrm{N}$ fertilization effect in soil is usually considered as being much ephemeral (Hutsch, 1998a), extended injurious effect (up to several weeks) has been observed in some studies (Suwanwaree and Robertson, 2005).

Higher DOC soil contents at $0-30 \mathrm{~cm}$ layer result from a large input of labile $\mathrm{C}$ on the soil surface of this no-tillage soil. Considering a mean bulk soil density of $1.4 \mathrm{Mg} \mathrm{m}^{-3}$, the variation of $0.36-0.13 \mathrm{mg} \mathrm{C} \mathrm{kg}^{-1}$ soil (maximum DOC content in the postmanagement period and background DOC content in the following period, respectively) represents an amount of $966 \mathrm{~kg} \mathrm{ha}^{-1}$ of DOC in $0-30 \mathrm{~cm}$ soil profile, which is concentrated mostly in soil surface layer. Thus, the intense biological oxidation of this labile $C$ source probably resulted in anoxic conditions, mainly in niches of high microbial activity, creating favorable conditions to methanogenesis (Baggs et al., 2006; Topp and Pattey, 1997). In addition, methanogenesis may have been favored by the highest values of water-filled soil porosity (up to 90\%; Khalil and Baggs, 2005) verified in the post-management period as a result of rainfall events (Fig. 4).

The close and negative relationship between the annual soil $\mathrm{CH}_{4}$ fluxes and annual aboveground biomass- $\mathrm{C}$ input by cropping systems (Fig. 5) is possibly related to the effect of soil quality restoring under high input cropping systems, increasing $\mathrm{CH}_{4}$ oxidation in soil. One exception was the cropping system with pigeon pea, which had the highest $\mathrm{C}$ and $\mathrm{N}$ inputs $\left(7.84 \mathrm{Mg} \mathrm{ha}^{-1}\right.$ and $327 \mathrm{~kg} \mathrm{ha}^{-1}$, respectively) and the highest values in most of the soil quality indicators. The soil under this summer cover crop species had the highest annual $\mathrm{CH}_{4}$ emission (+994 $\left.\pm 105 \mathrm{~g} \mathrm{C} \mathrm{ha}^{-1}\right)$, which was probably related to the longer and more intense injurious effect of the high input of biologically fixed $\mathrm{N}$ on soil $\mathrm{CH}_{4}$ uptake capacity.

According to our study, recovery of soil $\mathrm{CH}_{4}$ oxidation capacity is a very slow process and several decades are required to a significant effect of conservation management systems mitigating $\mathrm{CH}_{4}$ emissions from soil. This finding is the same of that obtained by Jacinthe and Lal $(2006,2005)$ and Suwanwaree and Robertson (2005) in temperate soils. In addition to the intrinsic slow recovery of soil $\mathrm{CH}_{4}$ oxidation capacity, our results suggest that the recovery of soil $\mathrm{CH}_{4}$ uptake capacity - as consequence of the improvement in soil quality - may be hampered by an injurious effect of longterm biologically fixed $\mathrm{N}$ input on soil methanotrophic microbiota, and by the occurrence of methanogenesis, as a result from $\mathrm{O}_{2}$ exhaustion in niches of high biological activity in the surface layer of the no-tilled soils. The distinct location of the zone of maximum 
$\mathrm{CH}_{4}$ oxidation (5-15 cm; Hutsch, 1998a; Jacinthe and Lal, 2006) in relation to the main layer of soil profile where soil quality is primarily improved $(0-5 \mathrm{~cm})$ should also be addressed in future studies aiming to evaluate its role on the low impact of conservation management systems on the recovery of soil $\mathrm{CH}_{4}$ sink strength.

\section{Conclusions}

No-till soil had net methane consumption or emission depending on the period of the year and on the cropping system. Greatest oscillation in soil methane fluxes was observed in the period after cover crops management in the spring season, when methane fluxes were closely related to the ammonium and dissolved organic carbon in soil. In general, a small decrease in the annual soil methane emissions was observed in high aboveground biomass-C input cropping systems, which was attributed to their favorable impact on biological, physical and chemical soil quality. We hypothesized that recovery of soil $\mathrm{CH}_{4}$ uptake capacity under high biomass input cropping systems has been restrained by an injurious effect of long-term biologically fixed $\mathrm{N}$ input on soil methanotrophic microbiota, and by the occurrence of methanogenesis in high biological activity niches in the surface soil layer of this no-tillage soil.

\section{Acknowledgments}

This project was funded by the Brazilian Council for Scientific and Technologic Development (CNPq) and Foundation of Research Support of Rio Grande do Sul State (Fapergs).

\section{References}

Acton, S.D., Baggs, E.M., 2011. Interactions between $\mathrm{N}$ application rate, $\mathrm{CH}_{4}$ oxidation and $\mathrm{N}_{2} \mathrm{O}$ production in soil. Biogeochemistry 103, 15-26.

Amado, T.J.C., Bayer, C., Conceição, P.C., Spagnollo, E., Campos, B.C., Veiga, M., 2006. Potential of carbon accumulation in no-till soils with intensive use and cover crops in Southern Brazil. Journal of Environment Quality 35, 1599-1607.

Baggs, E.M., Blum, H., 2004. $\mathrm{CH}_{4}$ oxidation and emissions of $\mathrm{CH}_{4}$ and $\mathrm{N}_{2} \mathrm{O}$ from Lolium perene swards under elevated atmospheric $\mathrm{CO}_{2}$. Soil Biology and Biochemistry $36,713-723$.

Baggs, E.M., Chebii, J., Ndufa, J.K., 2006. A short-term investigation of trace gas emissions following tillage and no-tillage of agroforestry residues in western Kenya. Soil and Tillage Research 90, 69-76.

Ball, B.C., Scott, A., Parker, J.P., 1999. Field $\mathrm{N}_{2} \mathrm{O}, \mathrm{CO}_{2}$ and $\mathrm{CH}_{4}$ fluxes in relation to tillage compaction and soil quality in Scotland. Soil and Tillage Research 53, 29-39.

Bayer, C., Martin-Neto, L., Mielniczuk, J., Ceretta, C.A., 2000. Effect of no-till cropping systems on soil organic matter in a sandy clay loam Acrisol from Southern Brazil monitored by electron spin resonance and nuclear magnetic resonance. Soil and Tillage Research 53, 95-104.

Bender, M., Conrad, R., 1992. Methane oxidation activity in various soils and freshwater sediments: occurrence, characteristics, vertical profiles, and distribution on grain size fractions. Journal of Geophysical Research 99, 1653116540.

Boeckx, P., Van Cleemput, O., 1996. Methane oxidation in a neutral landfill cover soil: influence of moisture content, temperature, and nitrogen-turnover. Journal of Environment Quality 25, 178-183.

Boeckx, P., Van Cleemput, O., 2001. Estimates of $\mathrm{N}_{2} \mathrm{O}$ and $\mathrm{CH}_{4}$ fluxes from agricultural lands in various regions in Europe. Nutrient Cycling in Agroecosystems 60, 35-47.

Bremner, J.M., 1960. Determination of nitrogen in soil by the Kjeldahl method. Journal of Agricultural Science 55, 11-33.

Chan, A.S.K., Parkin, T.B., 2001. Methane oxidation and production activity in soils from natural and agricultural ecosystems. Journal of Environment Quality 30, 1896-1903.

Chantigny, M.H., 2003. Dissolved and water-extractable organic matter in soils: a review on the influence of land use and management practices. Geoderma 113, 357-380.

Fontoura, S.M.V., Bayer, C., 2009. Adubação nitrogenada para alto rendimento de milho na região Centro-Sul do Paraná. Revista Brasileira de Ciência do Solo 33, 1721-1732.

Gomes, J., Bayer, C., Costa, F.S., Piccolo, M.C., Zanatta, J.A., Vieira, F.C.B., Six, J., 2009. Soil nitrous oxide emissions in long-term cover crops-based rotations under subtropical climate. Soil and Tillage Research 106, 36-44
Hutchinson, G.L., Livingston, G.P., 1993. Use of chamber systems to measure trace gas fluxes. In: Harper, L.A. (Ed.), Agricultural Ecosystem Effects on Trace Gases and Global Climate Change. ASA, CSSA e SSSA, Madison, (ASA Spec. Publ. 55), pp. 63-78.

Hutsch, B.W., 1998a. Tillage and land use effects on methane oxidation rates and their vertical profiles in soil. Biology and Fertility of Soils 27, 284-292.

Hutsch, B.W., 1998b. Methane oxidation in arable soil as inhibited by ammonium, nitrite, and organic manure with respect to soil pH. Biology and Fertility of Soils 28, 27-35.

Hutsch, B.W., 2001. Methane oxidation in non-flooded soils as affected by crop production - invited paper. European Journal of Agronomy 14, 237-260.

IPCC, 2007. Climate change 2007: Mitigation. In: Metz, B., et al. (Eds.), Contribution of Working Group III to the Fourth Assessment Report of the Intergovernmental Panel on Climate Change. Cambridge University Press, Cambridge, United Kingdom and New York.

Jacinthe, P.A., Lal, R., 2005. Labile carbon and methane uptake as affected by tillage intensity in a Mollisol. Soil and Tillage Research 80, 35-45.

Jacinthe, P.A., Lal, R., 2006. Methane oxidation potential of reclaimed grassland soils as affected by management. Soil Science 171, 772-783.

Jantalia, C.P., Santos, H.P., Urquiaga, S., Boddey, R.M., Alves, B.J.R., 2008. Fluxes of nitrous oxide from soil under different crop rotations and tillage systems in the South of Brazil. Nutrient Cycling in Agroecosystems 82, 161-173.

Kessavalou, A., Mosier, A.R., Doran, J.W., Drijber, R.A., Lyon, D.J., Heinemeyer, O., 1998 Fluxes of carbon dioxide, nitrous oxide, and methane in grass sod and winter wheat-fallow tillage management. Journal of Environment Quality 27, 1094-1104.

Khalil, M.I., Baggs, E.M., 2005. $\mathrm{CH}_{4}$ oxidation and $\mathrm{N}_{2} \mathrm{O}$ emissions at varied soil waterfilled pore spaces and headspace $\mathrm{CH}_{4}$ concentrations. Soil Biology and Biochemistry $37,1785-1794$

Knief, C., Vanitchung, S., Harvey, W., Conrad, R., Dunfield, P.F., Chidthaisong, A., 2005. Diversity of methanotrophic bacteria in tropical upland soils under different land uses. Applied and Environmental Microbiology 71, 3826-3831.

Kong, A.Y.Y., Six, J., Bryant, D.C., Denison, R.F., van Kessel, C., 2005. The relationship between carbon input aggregation, and soil organic carbon stabilization in sustainable cropping systems. Soil Science Society of America Journal 69, 1078-1085.

Mojeremane, W., Rees, R.M., Mencuccini, M., 2011. The effects of site preparation practices on carbon dioxide methane and nitrous oxide fluxes from a peaty gley soil. Forestry 19, 1-15.

Ojima, D.S., Valentine, D.W., Mosier, A.R., Parton, W.J., Schimel, D.S., 1993. Effect of land-use change on methane oxidation in temperate forest and grassland soils. Chemosphere 26, 675-685.

Powlson, D.S., Goulding, K.W.T., Willison, T.W., Webster, C.P., Hutsch, B.W., 1997. The effect of agriculture on methane oxidation in soil. Nutrient Cycling in Agroecosystems 49, 59-70.

Priemé, A. Christensen, S., 1999. Methane uptake by a selection of soils in Ghana with different land use. Journal of Geophysical Research - Atmospheres 104, 23617-23622.

Priemé, A., Christensen, S., Dobbie, K.E., Smith, K.A., 1997. Slow increase in rate of methane oxidation in soils with time following land use change from arable agriculture to woodland. Soil Biology and Biochemistry 29, 1269-1273.

Reay, D.S., Nedwell, D.B., 2004. Methane oxidation in temperate soils: effects of inorganic N. Soil Biology and Biochemistry 36, 2059-2065.

Regina, K., Alakukku, L., 2010. Greenhouse gas fluxes in varying soil types under conventional and no-tillage practices. Soil and Tillage Research 109, 144-152.

Schmitz, J.A.K., 2003. Biological indicators of soil quality. Doctorate Thesis in Graduation Program of Soil Science in Federal University of Rio Grande do Sul, Porto Alegre, RS, Brazil (in Portuguese).

Seghers, D., Top, E.M., Reheul, D., Bulcke, R., Boeckx, P., Verstraete, W., Siciliano, S.D., 2003. Long-term effects of mineral versus organic fertilizers on activity and structure of the methanotrophic community in agricultural soils. Environmental Microbiology 5, 867-877.

Sitauta, B., Hansen, S., Sitauta, J.I.B., Bakken, L.R., 2000. Methane oxidation potentials and fluxes in agricultural soil: effects of fertilization and soil compaction. Biogeochemistry 48, 323-339.

Smith, K.A., Dobbie, K.E., Ball, B.C., Bakken, L.R., Sitauta, B.K., Hansen, S., Brumme, R. Borken, W., Christensen, S., Priemé, A., Fowler, D., Macdonald, J.A., Skiba, U., Klemedtsson, L., Kasimir-Klemedtsson, A., Degorska, A., Orlanski, P., 2000. Oxidation of atmospheric methane in Northern European soils comparison with other ecosystems, and uncertainties in the global terrestrial sink. Global Change Biology 6, 791-803.

Suwanwaree, P., Robertson, G.P., 2005. Methane oxidation in forest, sucessional, and no-till agricultural ecosystems: effects of nitrogen and soil dirturbance. Soil Science Society of America Journal 69, 1722-1729.

Tlustos, P., Willison, T.W., Bakker, J.C., Murphy, D.V., Pavlikova, D., Goulding, K.W.T., Powlson, D.S., 1998. Short-term effects of nitrogen on methane oxidation in soils. Biology and Fertility of Soils 28, 64-70.

Topp, E., Pattey, E., 1997. Soils as sources and sinks for atmospheric methane. Canadian Journal of Soil Science 77, 167-178.

UNEP, 1993. United Nations Environment Programme, Environmental Data Report 1993-94. Blackwell, Oxford.

Ussiri, D.A.N., Lal, R., Jarecki, M.K., 2009. Nitrous oxide and methane emissions from long-term tillage under a continuous corn cropping system in Ohio. Soil and Tillage Research 104, 247-255.

Vieira, F.C.B., 2007. Stocks and lability of soil organic matter and acidification of a notilled Paleudult as affected by cropping systems and $\mathrm{N}$ fertilization. Doctorate Thesis in Graduation Program of Soil Science in Federal University of Rio Grande do Sul, Porto Alegre, RS, Brazil. 
Vieira, F.C.B., Bayer, C., Zanatta, J.A., Dieckow, J., Mielniczuk, J., He, Z.L., 2007. Carbon management index based on physical fractionation of soil organic matter in an Acrisol under long-term no-till cropping systems. Soil and Tillage Research 96, 195-204.

Vieira, F.C.B., Bayer, C., Mielniczuk, J., Zanatta, J.A., Bissani, C.A., 2008. Long-term acidification of a Brazilian Acrisol as affected by no till cropping systems and nitrogen fertilizer. Australian Journal of Soil Research 46, 17-26.

Willison, T.W., Webster, C.P., Goulding, K.W.T., Powlson, D.S., 1995. Methane oxidation in temperate soils - effects of land-use and the chemical form of nitrogen-fertilizer. Chemosphere 30, 539-546.
Zanatta, J.A., 2006. Stocks and lability of soil organic matter fractions in a Paleudult as affected by soil management systems. Master dissertation in Graduation Program of Soil Science in Federal University of Rio Grande do Sul, Porto Alegre, RS, Brazil (in Portuguese).

Zanatta, J.A., Bayer, C., Dieckow, J., Vieira, F.C.B., Mielniczuk, J., 2007. Soil organic carbon accumulation and carbon costs related to tillage cropping systems and nitrogen fertilization in a subtropical Acrisol. Soil and Tillage Research 94, 510-519.

Zanatta, J.A., Bayer, C., Vieira, F.C.B., Gomes, J., Tomazi, M., 2010. Nitrous oxide and methane in a South Brazilian Gleysol as affected by nitrogen fertilizers. Revista Brasileira de Ciência do Solo 34, 1653-1665. 